Andrej J. Borodichin

Nowosybirsk

\title{
Oddział Książki Rzadkiej i Rękopisów: kolekcje, działalność naukowa i popularyzatorska*
}

\begin{abstract}
I
Oddział Książki Rzadkiej i Rękopisów GPNTB SO RAN (Госудápственная публичная научно-техничческая библиоте́ка Сиби́рского отделе́ния Российской акаде́мии нау́к - Państwowa Publiczna Naukowo-Techniczna Biblioteka Oddziału Syberyjskiego Rosyjskiej Akademii Nauk) w Nowosybirsku posiada w swoich zbiorach cenne kolekcje staroruskich rękopisów i starych druków, druków osiemnastowiecznych wydanych zreformowaną cyrylica, tzw. „grażdanką”, dzieł pisarzy dziewiętnastowiecznych wydanych za życia autorów, wydań z okresu rosyjskiego srebrnego wieku, książek zakazanych, w tym nielegalnej miejscowej produkcji wydawniczej oraz wydań zagranicznych, związanych z działalnością rewolucyjną w Rosji, wydawnictw z okresu pierwszej rewolucji rosyjskiej, druków współczesnych, które są wzorcowymi przykładami sztuki edytorskiej i typograficznej, oraz wydań miniaturowych. Posiada także największą na wschodzie Rosji kolekcję książek zachodnioeuropejskich, datowanych od XV do początków XIX wieku. W chwili obecnej zasób Oddziału Książki Rzadkiej i Rękopisów liczy ponad 90000 jednostek i stale rośnie. Ramy chronologiczne księgozbioru obejmują okres od połowy XII wieku do dnia dzisiejszego.

Podstawą najstarszej części księgozbioru jest przekazany w latach 1967-1969 zbiór starych druków i rękopisów staroruskich należących do akademika Michaiła Nikołajewicza Tichomirowa. Ofiarowany Syberyjskiemu Oddziałowi Akademii Nauk ZSRR w Nowosybirsku zbiór liczy 686 rękopisów, ponad tysiąc dokumentów historycznych (XVII-XIX w.)
\end{abstract}

* Artykuł przygotowany przy pomocy finansowej Rosyjskiego Naukowego Funduszu Humanistycznego (projekt nr 15-01-18044/15) 
i 83 stare druki. Kolekcja Tichomirowa była jądrem, wokół którego z czasem narósł księgozbiór Oddziału Książki Rzadkiej i Rękopisów. Znajdziemy w nim: pochodzące z XIV wieku pergaminowe księgi Druckoje Jewangielije i Słowa św. Grzegorza Teologa oraz jeden z najstarszych dokładnie datowanych słowiańskich rękopiśmiennych kodeksów papierowych Słowa św. Grzegorza Teologa z 1362 roku, a także luksusowe iluminowane ewangeliarze $\mathrm{z}$ wieków XV-XVI, egzemplarze Psattiri i Apostoła $\mathrm{z}$ tego samego okresu, kodeksy zawierające utwory liturgiczne i narracyjne oraz wiele innych zabytków. W 1968 r. w Wydawnictwie Nauka (Moskwa) ukazał się drukowany inwentarz rękopisów z kolekcji Tichomirowa, zawierający zwięzłe informacje o pierwszych pięciuset dziełach $^{1}$. W wyniku regularnej działalności archeograficznej, zapoczątkowanej w Oddziale Syberyjskim Akademii Nauk ZSRR w ogległym już 1965 roku, kolekcja najstarszych rękopisów i druków biblioteki powiększyła się ponad dwukrotnie, zaczęto więc tworzyć wewnątrz niej wydzielone kolekcje terytorialne - m.in. tomską, zabajklaska, tuwińska, krasnojarska, kemerowską.

Wyodrębnienie kolekcji terytorialnych pozwala nie tylko na połączenie w jeden zbiór określonej grupy druków i zabytków piśmiennictwa, lecz także umożliwia zachowanie śladów migracji tych zabytków na terenach Syberii, dostarcza materiałów nieodzownych do studiów nad historią rozpowszechniania książki rosyjskiej na Syberii i historią syberyjskich bibliotek XVII-XIX w. Kolekcje terytorialne zawierają nie tylko rękopisy i stare druki, lecz także korespondencję chłopów, dokumenty i rysunki. $\mathrm{W}$ ten sposób dostrzeżono i udokumentowano wiele ważnych aspektów kultury duchowej o charakterze szerszym, typowym dla regionu, z którego pochodzą materiały włączone do zbiorów Oddziału².

W chwili obecnej Oddział Książki Rzadkiej i Rękopisów posiada ponad 1300 rękopisów staroruskich. Do najstarszych zabytków kolekcji tichomirowskiej dołączono znalezione na Syberii kodeksy rękopiśmienne z okresu XV-XVIII w., zawierające pisma Cyryla Turowskiego, Epifaniusza Mędrca, Nila Sorskiego, Józefa Wołockiego, modlitwy do pierwszych ruskich świętych Borysa i Gleba, Paterik kijewo-pieczerskij, Prologi z XV i XVI w., oraz traktat Pseudo-Dionizego Areopagity

${ }^{1}$ М. Н. Тихомиров, Описание Тихомировского собрания рукописей, Москва 1968.

2 В. Н. Алексеев, Об описании территориальных коллекиий фонда редких книг и рукописей ГПНТБ СО АН СССР, [w:] Проблемы научного описания рукописей и факсимильного издания памятников письменности: Материалы всесоюзной конференции, Ленинград 1981, s. 186. 
O niebiesnych ierarchijach w kopii z końca XV wieku. O szerokim rozpowszechnieniu na wschodnich obszarach Rosji ważnych zabytków literackich średniowiecznej Rusi świadczą odkryte w czasie badań terenowych kodeksy datowane od XV do XVII wieku, zawierające legendy i opowieści takie jak: O Mamajewom Poboiszcze, O carice Dinarie, O Pietrie i Fiewronij Muromskich, czernigowskom kniazje Michailie, żywoty świętych Aleksandra Newskiego, Sergiusza Radoneżskiego, metropolity Aleksego, Barłaama Chutyńskiego, utwory Iwana Groźnego i wiele innych znakomitych staroruskich dzieł literackich i historycznych.

Kolekcja obejmuje ponad dwa i pół tysiąca rosyjskich starodruków: wydania pierwszych drukarzy Iwana Fiodorowa i Piotra Mścisławca, typografów Nikifora Tarasijewa i Andronika Timofieja Newieży, Iwana Niewieżyna i Wasilija Burcowa, książki z drukarni ukraińskich i białoruskich (XVII-XIX w.), rozliczne wydania staroobrzędowców (XVIII poczatek XX wieku).

Zbiór osiemnastowiecznych rosyjskich drukowanych książek świeckich liczy ponad 2000 egzemplarzy, w tym - 262 woluminy ze sławnej biblioteki Kopalń Koływano-Woskresienskich, z której korzystali wybitni wynalazcy Iwan Iwanowicz Połzunow, Piotr Koźmicz Frołow, Andriej Iwanowicz Poroszyn. Zbiór ten zawiera rzadkie wydania Nikołaja Iwanowicza Nowikowa, Aleksandra Pietrowicza Sumarokowa, Wasilija Kiriłłowicza Triediakowskiego, Wasilija Iwanowicza Majkowa, Iwana Andriejewicza Kryłowa. Osobną część tego zbioru tworzą książki o tematyce naukowej - prace Michaiła Wasiljewicza Łomonosowa, Giercharda Fridricha (Fiodora Iwanowicza) Millera, Petera Simona Pallasa, Siergieja Sawwicza Wołczkowa i innych.

Perłą w kolekcji książek dziewiętnastowiecznych jest biblioteka wydanych za życia autora utworów Aleksandra Puszkina, którą otwiera pierwsza publikacja wiersza młodego poety Do przyjaciela-rymotwórcy w „Wiestnike Jewropy”. Zbiór zamykają pośmiertne już wydania utworów Puszkina $\mathrm{w}$ zapoczątkowanym przez niego samego czasopiśmie „Sowriemiennik”. W księgozbiorze Oddziału miejsce znalazły także wydane za życia utwory Mikołaja Gogola, Fiodora Dostojewskiego, Lwa Tołstoja, Nikołaja Leskowa, Gleba Uspieńskiego, Aleksieja Pisemskiego, Władimira Dala i wielu innych.

Pierwsze oraz inne wydane za życia utwory Aleksandra Błoka, Włodzimierza Majakowskiego, Wielemira Chlebnikowa, Wiaczesława Iwanowa, Konstantina Balmonta, Andrieja Biełego, Innokientija Annienskiego, Nikołaja Gumiliowa, Anny Achmatowej, Mariny Cwietajewej i wielu 
innych wspaniałych autorów znajdują się w kolekcji książek rosyjskiego srebrnego wieku.

Kolekcję wydawnictw związanych z ruchem rewolucyjnym w Rosji otwiera rządowa ulotka z XVIII w. Opisanie diet i sokruszenije złodeja i buntowszczika i samozwanca Jemeljana Pugaczowa; do zbioru tego włączone zostały przedrewolucyjne publikacje Putieszestwija iz Petierburga w Maskwu Aleksandra Radiszczewa, materiały i dokumenty dotyczące powstania dekabrystów, wydania Hercenowskiej Wolnej Drukarni Rosyjskiej w Londynie, podziemne wydania narodowolców. Tutaj znajduje się pierwsze rosyjskie wydanie Kapitału Karola Marksa i inne przedrewolucyjne wydania prac K. Marksa i Fryderyka Engelsa, pierwsze wydane za życia dzieła Włodzimierza Lenina. Bardzo interesująca jest kolekcja gazet i czasopism okresu pierwszej rewolucji rosyjskiej wydanych poza cenzurą. Do grona literatury historyczno-rewolucyjnej możemy zaliczyć także unikatowy zbiór broszur Wielkiej Rewolucji Francuskiej z XVIII w. Składa się nań ponad 400 druków, w tym Deklaracja praw człowieka i obywatela ${ }^{3}$.

Kolekcja druków zachodnioeuropejskich zawiera dziesięć inkunabułów; prace filozofów Arystotelesa, Platona, Lukrecjusza i rzadkie wydania z czasów odrodzenia; pierwsze wydania utworów Erazma z Rotterdamu, Francisa Bacona, Kartezjusza; traktaty z zakresu medycyny i botaniki Gariopontusa, Galena, Johannesa Mesue (Yuhanna ibn Masawaih) Starszego, Ambroise'a Paré, Andreasa Vesaliusa, Hieronymusa Fabriciusa, Paracelsusa, Karola Linneusza; prace z dziedziny fizyki i chemii Giovanniego Battisty della Porta, Johanna Glaubera, Ottona von Guericke, Roberta Boyle'a, Izaaka Newtona, Giovanniego Alfonso Borelliego, Christiaana Huygensa i wielu innych znanych uczonych.

Przechowywana w Oddziale Książki Rzadkiej i Rękopisów kolekcja druków miniaturowych (małoformatowych) należy zasadniczo do XX w., ale w charakterze cymeliów znajdują się w niej staroruskie oraz zachodnioeuropejskie rękopisy i książki drukowane od XVII do XIX wieku. W przeważającej części kolekcja ta została stworzona dzięki otrzymywanemu przez bibliotekę egzemplarzowi obowiązkowemu wszystkich książek wydanych w Federacji Rosyjskiej (ZSRR). Natomiast zagraniczne druki miniaturowe stanowią wyodrębnioną część pozyskanej przez nowosybirską bibliotekę prywatnej kolekcji książek miniaturowych (kolekcja Abrama Ruwinowicza Trachtenberga).

Р. М. Тонкова, Коллекичия брошюр эпохи Франиузской револющуии из собрания А.И. Шпагина, „Известия АН СССР. Отделение общественных наук”, 1934, s. 131-136. 


\section{II}

Zasadniczo wszystkie etapy pracy z materiałem bibliotecznym - gromadzenie, opracowanie i udostępnianie - są prowadzone przez pracowników w ramach działalności naukowej jednostki organizacyjnej.

Od 50 lat pracownicy Oddziału Książki Rzadkiej i Rękopisów wspólnie z wykładowcami, doktorantami i studentami Wydziału Humanistycznego Nowosybirskiego Uniwersytetu Państwowego i Nowosybirskiego Państwowego Konserwatorium prowadzą aktywną archeograficzną działalność terenowa, co jest głównym źródłem uzupełniania zbioru staroruskich rękopisów i starych druków. Pracochłonna, związana ze znoszeniem niewygód wypraw terenowych praca archeograficzna służy nie tylko uzupełnieniu zbioru staroruskich książek, lecz także przyczynia się do ratowania unikatowych zabytków dawnej książki rękopiśmiennej i drukowanej, poznania historii kolonizacji regionu Syberii przez wysiedleńców z różnych regionów Rosji.

Staroobrzędowcy rosyjscy to zjawisko unikatowe w światowej historii. Wzajemne stosunki staroobrzędowców z władzą świecką i duchowną na przestrzeni trzech i pół wieku składają się na bardzo ważne z różnych punktów widzenia doświadczenie powstania i rozwoju nastrojów opozycyjnych w społeczeństwie rosyjskim od XVII do XX w. W dzisiejszych czasach staroobrzędowcy stanowią w większości przykład pozytywnie zaadaptowanej przeszłości, która z kolei jawi się jako pomnik kultury minionych wieków, wymagający troski i uwagi.

$\mathrm{Na}$ terytorium obejmującym więcej niż połowę współczesnej Rosji staroobrzędowcy syberyjscy zdołali zachować dużą część tradycyjnej rosyjskiej kultury książki. Kultura ta, której początki sięgają środowisk staroobrzędowców z przełomu XVII i XVIII w., obejmuje po pierwsze praktycznie kompletny repertuar staroruskich utworów literackich od XI po XVII w., po drugie zaś wzbogacona została o nowe utwory odzwierciedlające wyobrażenia starowierców o sobie samych, o Rosji, jej historii i losach. Z tej perspektywy staroobrzędowcy syberyjscy moga i powinni być postrzegani także jako kontynuatorzy tradycji kolekcjonerskich przechowywania i wykorzystywania dziedzictwa piśmiennictwa staroruskiego, które to tradycje mają swoje źródła jeszcze w XIX wieku w heroicznej działalności mecenasów, księgarzy i kupców pochodzących ze środowisk starowierców, których kolekcje rękopisów i książek stały się prawdziwym skarbem stołecznych książnic Moskwy i Petersburga: Tichona Fiodorowicza Bolszakowa, Aleksieja Iwanowicza Chłudowa, Diemientija Wasiljewicza Piskariowa, Pietra Nikołajewicza Nikiforowa, 
Pawła Pietrowicza Szybanowa, Grigorija Matwiejewicza Prianisznikowa i wielu innych.

Doskonałym przykładem nieprzemijającego znaczenia dla rosyjskiej nauki historycznej i kultury kolekcji zebranych przez bibliofilów-staroobrzędowców jest niewielka pod względem bibliofilskim kolekcja A. I. Chłudowa, licząca nieco ponad 500 rękopisów (XII-XIX w.) i 700 druków cyrylickich. Wspomnijmy kilka rękopisów i starych druków z tego zbioru. Są to zabytki południowosłowiańskiego pochodzenia, takie jak Słowo Konstantyna Fiłosofa (XIV w.), z tego samego okresu apokryficzne Paralipomenon (Letopisi) proroka Jeremiasza i apokryficzna ewangelia apostoła Tomasza, Letovnik (Chronika) mnicha Grzegorza (XV w.); ponadto ruskie zbiory kazań metropolity Daniela, zbiór prac i przekładów Maksyma Greka, Proswietitiel Józefa Wołockiego, a także cudem ocalały rękopis Tworenij Jana Damasceńskiego w przekładzie księcia Andrieja Michajłowicza Kurbskiego; słowiańskie inkunabuły wydane w 1491 r. w Krakowie przez Szwajpolta Fiola: Czasosłow, Triod Postnaja i Triod Cwietnaja, a także Psattir Franciszka Skoryny z 1517 r. wydany w Pradze, tegoż Pjatikniże Moiseja z 1519 r., Apostol z 1525 r. wydany przez Iwana Fiodorowa i wiele innych ${ }^{4}$.

Przykład biblioteki A. I. Chłudowa nie został przytoczony przypadkowo. Względnie niedawno w ręce archeografów, pracowników Oddziału Książki Rzadkiej i Rękopisów GPNTB SO RAN, dostał się pochodzący z najnowszych czasów rękopis zatytułowany Powiesti ob obiteli i jejo osnowanii, ukazujący historię powstania, dogmatykę i cechy charakterystyczne sposobu życia tak zwanej wspólnoty „,bractwa Antoniego"'. Autorem tekstu i redaktorem komentarzy jest mieszkaniec rejonu turuchańskiego Kraju Krasnojarskiego, jeden z potomków pierwszych mieszkańców wspólnoty. Według Powiesti... wyjazd założyciela bractwa, Jegora Jegorowicza Rogowa (na chrzcie otrzymał imię Antoni), na półtora roku do Moskwy był momentem zwrotnym w dziejach wspólnoty. W stolicy poznał on „dyrektora biblioteki”, który pozwolił mu „zatrzymać się przy niej, czytać książki i wypisywać z nich, co trzeba"6. W przypisie

4 А. Попов, Описание рукописей и каталог книг церковной печати библиотеки А.И. Хлудова, Москва, 1872, s. 2-3, s. 1-54 (trzecia paginacja).

5 А. Ю. Бородихин, Перспективы археографического исследования старообрядческих поселений Нижнего Енисея, [w:] Современные проблемы археографии: Сб. статей по материалам конференции, проходившей в Библиотеке РАН 25-27 мая 2010 г., Санкт-Петербург 2011, s. 361.

6 Nowosybirsk, Państwowa Publiczna Naukowo-Techniczna Biblioteka Syberyjskiego Oddziału Rosyjskiej Akademii Nauk (Государственная Публичная НаучноТехническая Библиотека Сибирского Отделения Российской Академии Наук, dalej cyt. ГПНТБ СО РАН), Отдел редких книг и рукописей, Рукопись Красноярской территориальной коллекции, rps Q VI.36, k. 9. 
do tej wiadomości redaktor kodeksu pisze: „O ile nam wiadomo, była to biblioteka Chłudowa, jako że było wiele wypisów i odnośników do tej biblioteki"'.

Wypisy i odsyłacze do biblioteki A. I. Chłudowa odnaleziono także w odkrytym trzy lata temu w czasie wyprawy archeograficznej do Kraju Krasnojarskiego rękopiśmiennym kodeksie ojca Antoniego. Kodeks ten natychmiast zwrócił uwage archeografów swym kompletnym opracowaniem historycznych i dogmatycznych kwestii spornych wśród staroobrzędowców, do dziś będących przedmiotem polemik i dociekań między różnymi odłamami. Szczególne zainteresowanie wzbudza spis i repertuar materiałów literackich, będących zasadniczą treścią kodeksu.

Mimo uderzających podobieństw nie sposób mówić o identyczności wspomnianych bibliotek. Wykazują zbieżność pod względem zawartości i względnej dawności, różnią się jednak zasadniczo, jeśli chodzi o sposób i zasady kolekcjonowania i funkcjonowania księgozbiorów. Jeśli pierwsza kolekcja reprezentuje typowy przykład zainteresowań bibliofilskich, dostosowanych do możliwości poszukiwania książek w środowisku bliskim wyznaniowo, to druga jest raczej charakterystycznym dla swych czasów przykładem księgozbioru typowego dla wspólnot staroobrzędowców, rozprzestrzenionych w wielkiej liczbie na ogromnym terytorium od Uralu do Kraju Chabarowskiego i regionów nadmorskich.

Tendencja do kontynuowania tradycji kolekcjonerskich, przechowywania i wykorzystania literackiego dziedzictwa staroruskiego szczególnie wyraźnie przejawia się w późnych kompilacjach wypisów tworzonych indywidualnie, w których obok kwestii współczesnych przeprowadzono także aktualizację utworów pochodzących z odległej przeszłości. Za przykład takiego kodeksu posłużyć może zbiór kopii utworów polemicznych o charakterze narracyjnym znaleziony przez wyprawę archeograficzną w 2014 r. w Kraju Krasnojarskim. Jest to kodeks staroobrzędowy o różnorodnej zawartości zatytułowany Cwietnik, pochodzeniem i lokalizacją związany ze wspólnotami „,czasowiennych” - typowy wytwór dla tego kręgu odbiorców ${ }^{8}$. Podzielony został na kilka bloków tematycznych. Tytuł umieszczony na wyklejce wraz z informacją o właścicielce zbiorku, niejakiej Marij Zacharownie Prochorowej, dopełnia, niczym ostatnie pociagnięcie pędzla, obrazu całości jego historii. Papier tego ko-

7 Tamże, k. 73.

8 ГПНТБ СО РАН, Отдел редких книг и рукописей, Рукопись Красноярской территориальной коллекции, Сборник старообрядческий с Повестью о Дмитрии Басарге, Inv. № 42-14-2013, sygn. O VI.13 - rękopis z połowy XIX w., $8^{\circ}(16,5 \times 10,2 \mathrm{~cm})$, I +250 kk. Półustaw różnych kopistów, oprawa chałupnicza: deski, skóra, tłoczenia, dwie zastiożki, nota własnościowa „Марии Захаровны Прохоровой”. 
deksu pozwala datować całość na lata czterdzieste XIX wieku. Kompilację tworzą dzieła o charakterze eschatologicznym, polemicznym, a także dotyczace kwestii rytuału religijnego oraz historyczno-literackie i dokumentalne. Ponad sto wypisów z różnych utworów pochodzących z najstarszego okresu oraz z czasów rozłamu w cerkwi i prób przezwyciężenia schizmy daje nam wyobrażenie o ideologicznych i dogmatycznych dociekaniach, zainteresowaniach literackich i gustach kompilatora kodeksu oraz jego czytelników.

1. Zespół dzieł eschatologicznych składa się z tekstów utworów rosyjskich odwołujących się do Apokalipsy i komentarzy do tej księgi ojców i doktorów Kościoła. Z odniesieniami do rozdziału 25 księgi Szczit Wiery zamieszczona została historia o Antychryście - Kako roditsja $i$ wocaritsja, i prel'stit mnogi jazyki, $i$ sobieriet woinstwo straszno siebie $w$ żertwu na Isusa, syna Bożyja. Tematyka czasów ostatecznych jest kontynuowana wyborem z Knigi Andrieja Jurodiwowo z właściwymi temu kierunkowi piśmiennictwa obrazami, postaciami i zdarzeniami. Życie Awwadona-Antychrysta jest lustrzanym odbiciem życia Jezusa Chrystusa ze wszystkimi znaczącymi momentami: śmierci, zmartwychwstania, zstapienia do otchłani aż do kosmicznej bitwy z Synem Bożym i Jego wojskiem. Temat ten znajduje rozwinięcie $\mathrm{w}$ zestawie wypisów, rozpoczynającym się księga Tifologia, i jest kontynuowany w obszernych wypisach z mnicha Zinowia, z ksiag Złatoj bisier, Szczit wiery, Psattir, Azbucznyj Paterik, z Ewangelii według św. Łukasza, z pisma zatytułowanego Paterik egipski i z dzieła Cyryla Filozofa $O$ ljutych wriemienach wos'mogo wieka.

2. Następna część kompilacji to fragmenty z nielicznych, lecz bardzo znaczących dzieł o charakterze polemicznym. Składają się one na całość skierowana przeciwko heretykom, którzy nie pozwalają nad Ukrzyżowaniem umieszczać obrazu Boga Ojca. Dołączone jest także pouczenie O title na kriestie Gospodni. W zbiorze tym mieści się także pismo polemiczne zredagowane $\mathrm{w}$ formie pytań skierowanych do wiernych oficjalnego prawosławia.

3. Kolejny rozdział dotyczy liturgii i zasad życia chrześcijańskiego. Tworzą go różnego rodzaju reguły, zalecenia i polecenia skierowane do chrześcijanina, zaczerpnięte z Potrebnika, akt soborów i Nomokanonu. Tutaj zawiera się także obszerny wybór z Sobornowo ułożenija cara Aleksieja Michajłowicza, zakazującego używania tytoniu i handlu. Seria wypisków z apokryficznego utworu św. Łukasza Ewangelisty o ikonie Bogurodzicy, księgi Nikona Czarnogorca i księgi komentarzy do Apostoła zakończona jest opisem sakramentu chrztu według obrządku przyjętego u starowierców-czasowiennych - ,z obrotem”. W składzie Cwietnika 
ta część wyróżnia się wyraźnymi granicami, oznaczonymi kolofonem „Iz raznych knig".

4. Najbogatszy pod względem liczby wypisów, ich gatunkowej swoistości i pochodzenia jest rozdział Cwietnika o charakterze historycznoliterackim. Rozpoczyna się on przepięknym utworem Powiest'o Basargie (w „,redakcji weneckiej” według klasyfikacji Michaiła Osipowicza Skripila $)^{9}$, po czym następuje Skazanie o Wawilonskom Carstwie, nie wiedzieć czemu połączone z księgą Paterik Jerozolimskij. Po tych wyrazistych przykładach staroruskiej beletrystyki następują powieści z Wielikowo Zercała, opowieści zaczerpnięte z Prołogu: O premudrosti $i$ nakazanii, Poslanie Awgaria carja. Całości rozdziału dopełnia wybór utworów o symbolach chrześcijaństwa wraz z ich objaśnieniem: Swjatago Gennadija, patriarcha Konstantinagrada, skazanie o duze nebesnej, jeże est' rajduga, jako podobie est'Bożije; o symbolicznym znaczeniu przedmiotów użytku liturgicznego - traktat o kadzielnicy, a także Skazanije o lestowkie (z księgi Granograf); utwór w formie pytań-i-odpowiedzi o symbolicznym objaśnieniu postaci i wydarzeń z historii chrześcijaństwa - Jezusa Chrystusa, Bogurodzicy, męki Pańskiej, postaci starotestamentowych, niektórych przedmiotów z otaczającego świata. Tu mieści się także Prenije żiwota so smiert'ju, wątek młodej dziewczyny z Runa oroszennowo, opowiadania z Wielikowo zercała, w tym $O$ p'janice, iże prodadie duszu swoju diawołu. W końcowej części zbioru znajduje się utwór apokryficzny Sny Mamiera carja, z którym łączą się krótkie nowele w rodzaju $O$ niekojej wdowie, udiwitel'nyje szczedroty Bogorodicy, kończące się wypiskami z Zonary o karze za grzech cudzołóstwa, kradzieży, podpalenia, krzywoprzysięstwa, przekleństwa itp. Całość zamyka się krótkim traktatem o goleniu brody.

5. Jedyne dzieło w Cwietniku o charakterze dokumentalnym, traktujące o względnie nieodległej przeszłości, tj. o cerkiewnym rozłamie, poświęcone zostało biegłopopowskiemu ośrodkowi staroobrzędowstwa - Polskoj obłasti, riekie Wietkie. W skład utworu wchodzą elementy genealogii wspólnoty religijnej, czyniące założycielem tego odłamu ieromonacha-schimnika Fiedosija „przez patriarchę Józefa wyświęconego, przez Pawła kołomieńskiego pobłogosławionego". Pod względem ideologicznym utwór ten jest wzmocniony cytatami z Biesjed Jana Chryzostoma, księgi Ritorika, ze Słowa 12 Proswietitiela Józefa Wołockiego, które roztrząsają temat możliwości dokonania ,konsekracji także przez niegodnych kapłanów".

9 Повесть о Дмитрии Басарге и его сыне Борзосмысле, исслед. и подгот. текстов М. О. Скрипиля, Ленинград 1969. 
Obecność tego utworu wraz ze wspomnianymi już w poprzednich rozdziałach tekstami należącymi do tematyki obrzędowej, polemicznej i „eremickiej” pozwala wysnuć wniosek o zredagowaniu całego zbioru w kręgach starowierców-czasowiennych na Syberii lub na Uralu.

Badania nowosybirskich archeografów posiadają swoją specyfikę jest to unikatowe, kompleksowe podejście, gdzie każdą zabytkową książkę (lub też bibliotekę całej wspólnoty) rozpatruje się w kontekście jej typologicznych związków z dziedzictwem rosyjskiego średniowiecza, aktualizującym się w nowych warunkach i przejawiającym na kolejnym etapie istnienia uniwersalną zdolność do adaptacji w zmieniającym się świecie. Naukowe opracowanie funkcjonowania księgozbiorów staroobrzędowców należących do jednej z denominacji lub do lokalnej wspólnoty w perspektywie historycznej jest możliwe tylko z uwzględnieniem opisu dwóch rodzajów zespołów źródeł: zawartości bibliotek ,żyjących” (jest to zadanie archeografii terenowej) ${ }^{10}$, w porównaniu do posiadanych przez regionalne książnice kolekcji utworów staroruskich (jest to zadanie archeografii laboratoryjnej). Praca archeograficzna przeprowadzana w laboratorium jest ważnym aspektem działalności poszukiwawczej oddziału, w ramach której prowadzona jest redakcja i publikacja naukowych opracowań rękopisów i starych druków nie tylko ze zbiorów własnych GPNTB SO RAN, ale także z kolekcji i zbiorów innych bibliotek na terytorium Syberii i Dalekiego Wschodu. Działalność ta przebiega w ścisłej współpracy z pracownikami odnośnych instytucji, którym świadczona jest pomoc w opisie zabytków oraz w wydawaniu katalogów. Do chwili obecnej w ramach tego wielkiego i długoterminowego projektu wydano już 24 tomy tomy Materiałow k swodnomu katałogu rukopisiej, staropieczatnych i riedkich knig w sobranijach Sibirii i Dalniewo Wastoka. W 2014 r. wydano trzy kolejne tomy, które w oryginalny sposób oddaja unikalny charakter kolekcji cymeliów największej biblioteki w regionie. W wydaniach z 2014 r. poświęcono uwagę przede wszystkim prezentacji lokalnych grup książek pochodzących z kolekcji Tichomirowa oraz kemerowskiej kolekcji terytorialnej i zbioru druków wydanych tzw. grażdanką (XVIII - pierwsze trzydziestolecie XIX wieku).

Publikacji utworów jednego z najbardziej ,żywotnych” gatunków staroruskiej kultury - wierszy duchownych - jest poświęcona praca Tatiany

10 Е. И. Дергачева-Скоп, А. Ю. Бородихин, Сибирские старообрядческие «живые» библиотеки в составе электронного ресурса «Книжные памятники Сибири», [w:] Письменото наследство в информачионните технологии : материали от V междунар. науч. конф. (Варна, 15-20 септември 2014 г.), София - Ижевск 2014, s. $38-43$. 
Gienrichowny Kazancewoj Duchownyje stichi w rukopisnych sbornikach staroobrjadcew filipowskawo sogłasija (po materiałam Kemerowskawo territorialnawo sobranija GPNTB SO RAN ${ }^{11}$. Niezwykłość tej publikacji polega na pewnym odejściu od wyraźnie ukształtowanej tradycji wydawnictw Materiałow k Swodnomu Katałogu..., według której w kolejnych tomach zamieszczane są archeograficzne opisy książek rękopiśmiennych lub drukowanych należących do konkretnej kolekcji. W przypadku publikacji Kazancewoj specjaliści zajmujący się badaniami kultury staroobrzędowców, dostali możliwość zaprezentowania 97 przykładów wierszy duchownych spośród 160 utworów wchodzących w skład ośmiu rękopiśmiennych kodeksów staroobrzędowców-filipowców pochodzących z kolekcji kemerowskiej. Trzeba dodać, iż prawie jedna czwarta całości opublikowanych wierszy duchownych nie ma odpowiedników w publikacjach tego typu, włączając wydania przedrewolucyjne.

Jest to pierwsza próba tego rodzaju, a zbiór kemerowski wybrany był nieprzypadkowo. Kolekcja ta, zawierająca ponad 90 rękopisów i starych druków, jest uważana za jedną z najbardziej interesujących. Ściśle związana, szczególnie w części dwudziestowiecznej, z historią zasiedlania regionu Syberii przez przedstawicieli najróżniejszych grup i kierunków staroobrzędowców wyróżnia się nadzwyczajną, ,wielobarwnością” materiału. W jej skład wchodzi obok chronologicznie najdawniejszej warstwy książek drukowanych (wydania Iwana Fiodorowa, moskiewskie, wileńskie, kijowskie książki z okresu przed schizma) część rękopiśmienna, która poza drobnymi wyjątkami reprezentowana jest w większości przez kodeksy o charakterze literacko-polemicznym późnej tradycji rękopiśmienniczej. „Skrajny stopień odrzucenia wszystkiego, co świeckie [...], rezygnacja $\mathrm{z}$ tego co nowe, $\mathrm{w}$ tym także pochodzące $\mathrm{z}$ czasów obecnych, bazuje na względnie obszernym korpusie utworów, powstających w tym środowisku na przełomie XVIII-XIX wieku"12. Przygotowany do druku materiał został zgrupowany według zasady przynależności tekstów do określonych rodzajów wierszy: od archaicznych wierszy pokutnych oraz wierszy należących do tradycji epickiej po satyryczne utwory tradycji późniejszej. Książkę otwiera artykuł wstępny, rekonstruujący historycz-

11 Т. Г. Казанцева, Духовные стихи в рукописных сборниках старообрядцев филипповского согласия (по материалам Кемеровского территориального собрания ГПНТБ СО РАН), Новосибирск 2014, (Материалы к Сводному каталогу рукописей, старопечатных и редких книг в собраниях Сибири и Дальнего Востока; Книжные памятники и книжные собрания).

12 А. Ю. Бородихин, О двух старообрядческих библиотеках, [w:] Сендьмые Макушинские чтения: материалы науч. конф., 16-17 мая 2006 г., г. Красеноярск, Новосибирск 2006, s. 16. 
no-etnograficzny kontekst bytowania liryki duchownej. Jako aneks załączono źródłoznawczy opis materiałów rękopiśmienniczych związanych $\mathrm{z}$ tym wydaniem.

Kolejnym ważnym przykładem pracy wydawniczej Oddziału było ukazanie się katalogu arabskich i tureckich rękopisów GPNTB SO $\mathrm{RAN}^{13}$. W katalogu tym zawarto informacje o rękopisach ,pochodzenia orientalnego" zidentyfikowanych pośród 24 manuskryptów w językach łacińskim, ormiańskim, niemieckim i polskim, które trafiły do biblioteki na podstawie testamentu akademika M. N. Tichomirowa. W literaturze przedmiotu rzadko wspomina się o istnieniu tych muzułmańskich rękopisów. Informacje o nich znajdziemy w krótkim szkicu Nikołaja Nikołajewicza Pokrowskiego i Aleksandra Iwanowicza Rogowa ${ }^{14}$, powstałym jeszcze przed przemieszczeniem kolekcji z Moskwy do Nowosybirska, oraz $\mathrm{w}$ fundamentalnej bibliografii rękopisów arabskich ${ }^{15}$; informacje te powtórzono w 1990 r. w publikacji Władimira Wiaczesławowicza Polosina $^{16}$. Od tamtego czasu nikt nie zajmował się orientalnymi rękopisami $\mathrm{z}$ tej kolekcji.

Podstawą kolekcji M. N. Tichomirowa były zbiory lekarza, docenta Wojskowej Akademii Medycznej, kolekcjonera książek staroruskich z Leningradu i historyka medycyny staroruskiej Witalija Fieofanowicza Gruzdiewa ${ }^{17}$. Są podstawy, by przypuszczać, iż także orientalną część kolekcji Tichomirow pozyskał od W. F. Gruzdiewa. Odnalezione przez Ilję Władimirowicza Zajcewa dokumenty archiwalne potwierdzają to przypuszczenie.

Opisana w katalogu muzułmańska część kolekcji liczy siedem rękopisów w języku arabskim i tureckim. Oprócz tego do katalogu włączo-

${ }_{13}$ И. В. Зайцев, Арабские и туреикие рукописи Государственной публичной научно-технической библиотеки Сибирского отделения РАН в Новосибирске, сост., вступит. ст., коммент. и описание рукописей И. В. Зайцева, науч. ред. А. Ю. Бородихин, Новосибирск 2014 (Материалы к Сводному каталогу рукописей, старопечатных и редких книг в собраниях Сибири и Дальнего Востока; Книжные памятники и книжные собрания).

14 А. И. Рогов, Н. Н. Покровский, Собрание рукописей академика М. Н. Тихомирова, переданное Сибирскому отделению АН СССР, „Археографический ежегодник за 1965 год", 1966, s. 162-172.

15 Библиография арабских рукописей, сост.: И. Б. Михайлова, А. Б. Халидова, отв. ред. А. Б. Халидов, Москва 1982.

16 В. В. Полосин, Фонды рукописей и старопечатных книг, актовых и эпиграфических материалов на языках народов советского и зарубежного Востока в СССР, [w:] Archeographia Orientalis: Mатериаль Всесоюз. рабочего совещ. по проблемам вост. археографии (Ленинград, 1 - 4 марта 1988 г.), Москва 1990, s. $178-204$.

17 В. И. Малышев, Об одном важном источнике Тихомировского собрания (Страничка воспоминаний), „Труды Отдела древнерусской литературы”, t. 32, Ленинград 1977, s. 395-401. 
no opis jednej książki litografowanej w języku uzbeckim oraz fragment rękopisu nieznanego dzieła w języku arabskim dotyczącego szariatu. W opinii redaktora katalogu, materiały niewchodzące w skład kolekcji M. N. Tichomirowa należały najprawdopodobniej do pierwszego nowonikołajewskiego (nowosybirskiego) imama-chatiba Garifa Walejewa.

Dzięki temu katalogowi po raz pierwszy zostały wprowadzone do obiegu naukowego materiały z „orientalnej części” zbioru Tichomirowa. Opis źródłoznawczy zawiera informacje o autorze, tytuł utworu, wymiary i objętość rękopisu (wydania), informacje o stanie zachowania i o oprawie, o rodzaju papieru, informacje paleograficzne i o atramencie. W opisie znajdziemy także incipit oraz informacje o treści utworu. Oprócz tego zawiera on ważne wiadomości źródłowe o glosach, marginaliach, znakach kopisty, czytelników i właścicieli i o pieczęciach. Wydanie jest zaopatrzone w indeksy i kolorowe ilustracje.

Ostatni wydany tom Materiałow k Swodnomu Katałogu... jest poświęcony opisaniu rosyjskich druków świeckich z bibliotek Kopalń Koływano-Woskriesienskich, zgromadzonych w Oddziale Książki Rzadkiej i Rękopisów GPNTB SO RAN ${ }^{18}$. Publikacja udostępnia badaczom obszerny materiał wyraźniej zarysowujący rozwój kultury książki w górniczym regionie, jej związki z ideowymi i duchowymi nurtami epoki oraz rozwojem produkcji górniczo-przemysłowej na Syberii. Do katalogu włączono 262 opisy egzemplarzy zabytków książkowych (z lat 1752-1824). Struktura i kolejność opisu w katalogu przedstawia się następująco: opis bibliograficzny; format; rozmiary bloku książki; odsyłacz do Swodnowo katałoga; sposoby paginacji; sygnatura; cechy charakterystyczne egzemplarza: sygnatura indywidualna, tłoczenia, odręczne zapiski, naklejki, stemple techniczne; oprawa; stan zachowania; zawartość treściowa; spis ilustracji; numer inwentarza.

Egzemplarze wydań z kolekcji kopalń zawierają liczne tłoczenia, sygnatury, zapiski, notatki, stemple techniczne, które odzwierciedlają historię tej biblioteki. Wszystkie etapy historii książek w tym zbiorze znalazły odbicie na kartach większości egzemplarzy.

Przebywanie każdej książki w zbiorach wspomnianych powyżej bibliotek odcisnęło swoje piętno w licznych sygnaturach, tworzonych według zasad inwentaryzacji i klasyfikacji bibliotecznej obowiązujących

18 Т. А. Драгайкина, Русские книги гражданской печати собрания КольвваноВоскресенских горных заводов в фонде ГПНТБ СО РАН, сост.: Т. А. Драгайкина, вступит. ст. И. А. Гузнер, Т. А. Драгайкиной, науч. ред. А. Ю. Бородихин, Новосибирск 2014 (Материалы к Сводному каталогу рукописей, старопечатных и редких книг в собраниях Сибири и Дальнего Востока; Книжные памятники и книжные собрания). 
w danym czasie, pieczęciach technicznych, zapiskach, świadczących o rejestracji egzemplarzy. Katalog ten odróżnia od innych podobnych zaprezentowanie pełnego zestawu jednostek wydawniczych, zawierających informacje o organizacji tekstu w książce (rozdziały, części itp.). Zamieszczono w nim także spis materiałów ilustracyjnych (szkice, mapy, grawiury). Katalog został opatrzony bibliografią prac poświęconych bibliotekom Kopalń Koływano-Woskriesienskich oraz indeksami: chronologicznym, tytułowym i osobowym.

Praca naukowo-badawcza Oddziału Książki Rzadkiej i Rękopisów jest prowadzona w ramach projektu realizowanego wspólnie z Katedrą Literatury Dawnej i Badań Źródłowych Wydziału Humanistycznego Nowosybirskiego Uniwersytetu Państwowego, zatytułowanego Tradicionnaja Russkaja Kniżnost'w Sibiri (Russkaja Kniga w Dorewolucjonnoj Sibiri). Publikacje katalogów opisujących rzadkie zbiory bibliotek syberyjskich, seria tematyczna Russkaja Kniga w Dorewolucjonnoj Sibiri oraz Kniga $i$ Literatura, a także wiele monografii to poważny i wymierny rezultat tej działalności.

\section{III}

Nowe kierunki pracy Oddziału Książki Rzadkiej i Rękopisów wiążą się z wykorzystaniem technologii elektronicznych i komputerowych. Po pierwsze, regularnie odbywa się praca związana z tworzeniem kopii zabezpieczających rękopisów i starych druków najstarszych kolekcji GPNTB SO RAN, co z kolei w przyszłości będzie podstawą do stworzenia biblioteki cyfrowej unikatowych zabytków książkowych Syberii i Dalekiego Wschodu. Po drugie, trwaja prace nad rozbudową bibliograficznych i pełnotekstowych baz danych, dających wyobrażenie o istnieniu w księgozbiorze Oddziału i w bibliotekach regionu syberyjskiego zabytków książkowych kraju ${ }^{19}$.

W chwili obecnej specjaliści-bibliolodzy, archeografowie, filolodzy i historycy maja do dyspozycji wersje elektroniczne (w postaci CD-R, DVD-R) najcenniejszych rękopisów i książek z kolekcji Tichomirowskiej, kolekcji krasnojarskiej, ałtajskiej i dalekowschodniej, z księgozbioru GPNTB SO RAN, zbiór wydanych za życia autora utworów A. S. Puszkina, 430 numerów czasopisma „Wiestnik Jewropy” (z lat 1801-1821), a także dokumenty z archiwum tobolskiego i z Państwowego Muzeum - Skansenu Historyczno-Architektonicznego w Tobolsku.

19 Dostępny na serwerze ГПНТБ СО РАН < www.spsl.nsc.ru>, zakładka „Цифровая библиотека «Книжные памятники Сибири»". 
Rozrastające się ciagle pełnotekstowe bazy danych są dostępne na stronie internetowej GPNTB SO RAN w formie biblioteki cyfrowej. Dają szerokiemu gronu czytelników możliwość zapoznania się praktycznie w oryginale z rękopisami od XIV do XVIII wieku, wydaniami pierwszych rosyjskich drukarzy, wydanymi za życia autorów dziełami wielkich pisarzy i poetów rosyjskich wieku XIX, rzadkimi wydaniami naukowymi, rękopisami i książkami z archiwum i muzeum historycznoarchitektonicznego pierwszej stolicy Syberii - Tobolska. Jednocześnie dzięki digitalizacji, stan tych cennych obiektów pozostaje nienaruszony.

Wi e stnik Jew ropy $1802-1821$. Baza danych „Wiestnik Jewropy" to pełne teksty numerów czasopisma od 1802 roku, które przechowywane są w księgozbiorze Oddziału Książki Rzadkiej i Rękopisów GPNTB SO RAN. „Wiestnik Jewropy” był pierwszym rosyjskim czasopismem literacko-kulturalnym, w którym obszernie przedstawiano między innymi zagadnienia zewnętrznej i wewnętrznej polityki Rosji, a także historię i życie polityczne obcych państw. „Wiestnik Jewropy” ukazywał się w Moskwie w latach 1802-1830, dwa razy w miesiącu. Czasopismo założył Nikołaj Michajłowicz Karamzin. W części czasopisma poświęconej literaturze w różnych okresach publikowali Gawriił Romanowicz Dierżawin, Nikołaj Michajłowicz Karamzin, Wasilij Andriejewicz Żukowski, Wasilij Lwowicz Puszkin, Michaił Matwiejewicz Chieraskow, Konstantin Nikołajewicz Batiuszkow, Pawieł Andriejewicz Wiaziemski, Dienis Wasiljewicz Dawydow, tutaj debiutowali Aleksander Puszkin, Aleksandr Siergiejewicz Gribojedow, Anton Antonowicz Delwig, Iwan Iwanowicz Puszczin.

Wydane za życia autora dzieła A. S. Puszkina. Baza ta zawiera pełne teksty utworów A. S. Puszkina, które ukazały się od 1814 do 1836 r., zarówno samoistnie, jak i w zbiorach, almanachach czy czasopismach tej epoki i przechowywane są w zbiorach Oddziału Książki Rzadkiej i Rękopisów GPNTB SO RAN.

Epoka Puszkina w zabytkach piśmiennictwa. Pełnotekstowa baza danych zawiera teksty utworów nauczycieli i wychowawców A. S. Puszkina, jego przyjaciół i oponentów, jego poprzedników, jemu współczesnych i następców.

K o l e k c j a Ti c h o m i r o w s k a. Na bazę tę składają się z pełnotekstowe kopie cyfrowe 72 najbardziej interesujących rękopisów, datowanych od XIV do XIX wieku, ze zbioru słynnego radzieckiego historyka, akademika Michaiła Nikołajewicza Tichomirowa.

Wydania I wan a Fi o d orowa. Pełnotekstowa Baza Danych „Wydania Iwana Fiodorowa” zawiera cyfrowe kopie pięciu wydań 
pierwszego rosyjskiego drukarza Iwana Fiodorowa - moskiewskiego Apostoła, pierwszej dokładnie datowanej książki rosyjskiej, lwowskiego Apostoła, zabłudowską Jewangeliję, ostrogskiego Nowogo Zawieta so Psałtyrju oraz Biblii - pierwszego pełnego wydania kanonu Pisma świętego w języku cerkiewno-słowiańskim.

Kolekcje terytorialne. W pełnotekstowej Bazie Danych „Kolekcje terytorialne” znajduje się 17 staroruskich rękopisów i starych druków, wśród których znajdują się egzemplarze tak cenne jak Soczinienija Pseudo-Dionizego Areopagity z XV wieku i zbiór rękopisów należący do Iony Dumina, zawierający Sudny spisok Maksima Greka. Kolekcja zawiera: trzynaście rękopisów ze zbioru krasnojarskiego, jeden rękopis ze zbioru ałtajskiego, jeden rękopis ze zbioru tomskiego, jeden rękopis ze zbioru dalekowschodniego oraz jeden rękopis ze zbioru wpływu bieżącego.

W y d a n i a X I X - X X w. Baza Danych z pełnymi tekstami „Wydania XIX-XX w." zawiera interesujące edycje prac naukowych i literatury pięknej (18 egzemplarzy). Wśród nich są wydane za życia autora dzieła N. W. Gogola i F. M. Dostojewskiego, część pamiętników członka rządu Aleksandra Wasiljewicza Kołczaka Gieorgija Konstantinowicza Ginsa Sibir, sojuzniki i Kołczak: 1918-1920, t. 2, części 2 i 3, wydane na emigracji w Pekinie i Charbinie w 1921 roku, wielotomową pracę naukową Aleksandra Nikołajewicza Wiesiełowskiego Razyskanija w obłasti russkawo duchownawo sticha, wydaną w latach 1879-1891, i inne.

Rękopisy i stare druki miasta Tobolska. Baza ta jest szczególnie wartościowa, ponieważ pierwsza stolica Syberii jest dziś oddalona od centrów życia naukowego i jej cymelia są przez to trudno dostępne dla większości badaczy. Baza zawiera kopie cyfrowe 22 egzemplarzy książek i rękopisów z Państwowego Archiwum w Tobolsku i Muzeum - Skansenu Historyczno-Architektonicznego w Tobolsku. Wśród nich - Chronograf z połowy XVII w. i wspaniała Czeriepanowskaja letopis'.

Wydania elektroniczne:

- Alekseew W. N., Borodichin A. J., Dergaczewa-Skop E. I., Szabanow A. W., Dejanija i posłanija sviatych apostot, Moskwa 1546. Drukarze Iwan Fiodorow i Piotr Mścisławiec. Egzemplarz SO RAN [wydanie elektroniczne]. - [Nowosybirsk] 2004. - (Seria „Kniżnyje Pamjatniki Sibiri"). - 1 CD-ROM

- Alekseew, W. N., Borodichin A. J., Dergaczewa-Skop E. I., Szabanow A. W, Biblia, Ostrog 1581. Drukarze - Iwan Fiodorow [źródło elektroniczne]. - Nowosybirsk 2006 - (Seria „Zabytki Książkowe Syberii”). - 1 CD-ROM 
- Jevangelije uczitelnoje Iwana Fiodorowa i Petra Timofiejewicza Mstisławca. [Źródło elektroniczne]. Autorzy-red.: Dergaczewa-Skop E. I., Borodichin A. J., Szabanow A. W., Nowosybirsk 2012 - Dane wyjściowe oryginału: Zabłudow: Typ. G. A. Chodkiewcza: Druk. Iwan Fiodorow, Piotr Timofiejew Mścisławiec, 17 marca 1569 r. (Seria „Kniżnyje Pamjatniki Sibiri: Egzemplarz GPNTB SO RAN" nr państw. rejestracji - 0321203513.) - DVD

\section{IV}

O wadze każdej kolekcji, każdego muzeum decydują przedmioty oryginalne; bogata historia gromadzenia całego księgozbioru GPNTB SO RAN i wyspecjalizowanego księgozbioru ksiag rzadkich i rękopisów stworzyły żyzną glebę dla uwieńczonego sukcesem pomysłu, jakim jest Muzeum Książki. Muzeum to zostało stworzone w oparciu o zbiory Oddziału Książki Rzadkiej i Rękopisów decyzją Rady Naukowej GPNTB SO RAN (Protokół nr 4 z zebrania Rady Naukowej GPNTB SO RAN z 18 VI 1991).

Muzeum Książki odwiedza ponad pięć tysięcy osób w ciagu roku, wśród których są studenci, doktoranci i wykładowcy uczelni, pracownicy naukowi zainteresowani historycznymi poszukiwaniami i odkryciami swoich kolegów, badacze z innych miast Rosji i z zagranicy. W sali wystawowej Muzeum Książki corocznie organizowanych jest nie mniej niż dziesięć wystaw, które dają czytelnikom i odwiedzającym możliwość zobaczenia praktycznie wszystkich cennych obiektów, które są tu przechowywane. „Dawne książki Syberii”, „Zachodnioeuropejska myśl, XV-XVIIIw.”, „IwanFiodorowidrukarstwo słowiańskie, XVI-XVIIIw.”, „Kultura dawnej Rusi w zabytkach piśmiennictwa, architektury i malarstwa ikonowego”, „Syberia w oczach podróżników z Europy zachodniej”, „Książki dawnych lekarzy”, „, Łomonosow i jego epoka”, „,Wolne drukarstwo rosyjskie od Hercena do naszych czasów", cykl wystaw poświęconych Puszkinowi, „Stulecie pierwszej rewolucji rosyjskiej 1905-1907”, „Opowieści wojskowe dawnej Rusi” - to tylko kilka przykładów wystaw zorganizowanych przez Muzeum Książki.

Częstymi gośćmi w muzeum są uczniowie szkół podstawowy, liceów i gimnazjów, przychodzący nie tylko w ramach wycieczek; muzeum stwarza możliwość prowadzenia lekcji o literaturze rodzimej i zagranicznej z wykorzystaniem bogatych możliwości, jakie daje księgozbiór Oddziału Książki Rzadkiej i Rękopisów. Studenci wydziałów humanistycznych co roku odbywają w muzeum praktyczną część zajęć z historii rodzimej kultury, literatury, paleografii i tekstologii. Wielostronna nauko- 
wa i popularyzatorska działalność Muzeum Książki już dawno uczyniła tę jednostkę organizacyjną biblioteki jednym z najpełniej wykorzystywanych centrów działalności wychowawczej i edukacyjnej, znaczącym zjawiskiem w społecznym i kulturalnym życiu Nowosybirska.

tłum. Barbara Chmielewska

\section{Streszczenie}

\section{Oddział Książki Rzadkiej i Rękopisów: kolekcje, działalność naukowa i popularyzatorska}

Oddział Książki Rzadkiej i Rękopisów GPNTB SO RAN (Госуда́рственная публи́чная научнно-техни́ческая библиоте́ка Сиби́рского отделе́ния Российской акаде́мии нау́к - Państwowa Publiczna Naukowo-Techniczna Biblioteka Oddziału Syberyjskiego Rosyjskiej Akademii Nauk) przechowuje znaczące zbiory książek i archiwaliów powstałych w okresie od XIII w. do dnia dzisiejszego. Ogólna liczba zbiorów przekracza obecnie 90000 jednostek; zbiory są systematycznie uzupełniane.

Podwaliny najstarszej części zbiorów stanowi kolekcja starych druków i rękopisów akademika M. N. Tichomirowa, którą Biblioteka otrzymała w latach 19671969. Ekspedycje archeograficzne organizowane przez Syberyjski Oddział RAN, przyczyniły się do ponad dwukrotnego powiększenia najstarszej części zasobów Biblioteki i powstania osobnych kolekcji terytorialnych. Do dzisiaj ten kierunek prac Oddziału stanowi perspektywiczny sposób uzupełniania najstarszej części kolekcji.

W chwili obecnej Oddział Książki Rzadkiej i Rękopisów dysponuje ponad 1300 staroruskich rękopisów i 2500 rosyjskich starodruków, doliczając do tego zbioru wydania drukarń staroobrzędowców XVIII-XIX w. Z innych kolekcji wyodrębniono książki XVIII w. drukowane tzw. grażdanka, a także wydane za życia autorów utwory rosyjskich pisarzy XIX w. i rosyjskiego srebrnego wieku oraz kolekcję prohibitów - wydanych nielegalnie i zagranicznych.

Równolegle do terenowej pracy archeograficznej Oddział gromadzi materiały do zbiorczego katalogu wydań rzadkich i książek zabytkowych przechowywanych w zasobach państwowych bibliotek na terytorium Syberii i Dalekiego Wschodu. Regularnie wydawane są katalogi rękopisów, starych druków i książek rzadkich. W związku z wykorzystywaniem nowych technologii i techniki cyfrowej pojawiają się nowe kierunki pracy Oddziału. Planowo przeprowadza się prace polegające na wykonywaniu cyfrowych kopii zabezpieczających rękopisy i druki, prowadzone są prace nad tworzeniem baz danych - bibliograficznych i pełnotekstowych - zawierających informację o dawnych książkach zabytkowych w regionie syberyjskim. 
W oparciu o zbiory Oddziału zostało stworzone i funkcjonuje Muzeum Książki, które prowadzi działalność naukowo-popularyzatorską dla placówek edukacyjnych miasta, mieszkańców Nowosybirska i wszystkich zainteresowanych historią kultury książki.

Słowa kluczowe: stare druki - rękopisy - źródłoznawstwo - kolekcje - Syberia.

\section{Summary}

\section{The Division of Rare Books and Manuscripts, SPSTL SB RASc: collections, scientific acitivities, and popularisation}

The Division of Rare Books and Manuscripts of the State Public Scientific Technological Library of the Siberian Branch of the Russian Academy of Sciences (Госуда́рственная публи́чная нау́чно-техни́ческая библиоте́ка Сиби́рского отделе́ния Российской акаде́мии нау́к) houses significant collections of printed matter and archival materials, dated from the $13^{\text {th }}$ century until today. The general number of items held has surpassed 90.000 . The collections are constantly developed.

The core of the oldest part of the holdings came with the legacy of the Academician M. Tikhomirov, received by the Library during the years 1967-1969. Other important acquisitions came from special field expeditions organised by the Siberian Branch of the RASc. These activities resulted in doubling the number of the oldest part of the holdings, and in setting up of separate territorial collections. This type of field work is still continued.

To date, the holdings of the Division of Rare Books and Manuscripts encompass over 1300 old Russian manuscripts and 2,500 of Cyrillic old prints (including the publications of the Old Believers, $18^{\text {th }}-19^{\text {th }}$ century). Eighteenth-century prints executed with the Cyrillic types westernized by Peter the Great form a separate collection; similarly, nineteenth-century works of Russian authors printed during their lifetimes, as well as by the authors of the Russian Silver Age (beginning of the $20^{\text {th }}$ century). Books prohibited by Soviet law, printed both in Russia and abroad, are also kept separately.

Alongside field work, the staff of the Division is gathering materials towards a union catalogue of old and rare books held at state repositories in Siberia and the Russian Far East. Catalogues of manuscripts, old prints, and rare books are regularly published. The arrival of digital technology resulted in new activities of the Division. Digitisation of materials is systematically carried out for preservation purposes and for databases - bibliographical and full text - devoted to Siberian history. 
Thanks to the holdings of the Division the Museum of the Book was organised, which conducts popularisation activities for the educational institutions of Novosibirsk, the inhabitants of the city, and all persons interested in the history and culture of the book.

Key words: early modern printed books - manuscripts - historical sources collections - Siberia. 